\title{
Genotyping of HF Crossbred Breeding Bulls for A1/A2 Variant of $\beta$-Casein Gene
}

\author{
Trupti V. Kulkarni, Vikrant D. Pawar, Rahul S. Deshmukh, Mahadeo P. Sawane
}

10.18805/IJAR.B-4726

\begin{abstract}
Background: The variants of $\beta$-casein (CSN 2) gene viz. A1 and A2 are supposed to be related with human health. Hence, to know the status of breeding bulls used for Al services were screened for A1 and A2 variants. Total 47 blood samples of crossbred breeding bulls from Frozen Semen Laboratory, Pune and Aurangabad were used for present work.

Methods: The extraction of genomic DNA by phenol-chloroform method were carried out from the blood samples of 47 breeding bulls. Further, DNA based PCR-RFLP method was used to identify the A1, A2 variants. Pure DNA fragments of $\beta$-casein (CSN 2) gene were amplified by PCR using suitable pairs of primer to amplify $121 \mathrm{bp}$ and $244 \mathrm{bp}$ products. The primer used to amplify 244 bp was allele specific. The $121 \mathrm{bp}$ fragment then subjected to restriction enzyme digestion. The restriction enzyme digestions resulted into two types of band pattern. The $244 \mathrm{bp}$ fragment was used for validation of $\mathrm{A} 1$ and $\mathrm{A} 2$ allele of $121 \mathrm{bp}$.

Result: Two types of genotypes i.e. A1A2 and A2A2 were revealed in the experimental population of HF crossbred breeding bulls. The genotypic frequency of $A 1 A 2$ and $A 2 A 2$ was estimated 65 and 35 per cent, respectively. The present frequency status of $A 1$ and $A 2$ allele in the breeding bulls may be suggested for planning future breeding strategy in dairy cattle.
\end{abstract}

Key words: A1/A2 variant, $\beta$ casein, Breeding bulls, Genotyping.

\section{INTRODUCTION}

The world is trending with the A2 milk brand which is the 'Original milk' by the dairy cows producing only A2- $\beta$-casein protein. Initially, there was existence of only $A 2$ variant of $\beta$ casein A2A2 genotype. The occurrence of A1 was due to mutation occurred during the process of selective breeding for high milk production. The mutations resulted into 13 variants of $\beta$-casein gene as $A 1, A 2, A 3, A 4, B, C, D, E, F$, $H 1, H 2, I$ and $G$ (Roginsky, 2003). A1 and $A 2$ variants of $\beta-$ casein protein differ in structure, $A 1$ has histidine at $67^{\text {th }}$ position and A2 has proline at the same position (Sharma et al., 2013). There is polymorphism at codon 67 of $\beta$-casein gene, CCT which codes for proline in A2 $\beta$-casein changes to CAT which codes histidine in A1 $\beta$-casein (Ganguly et al., 2013a). The structural difference in A1 and A2 $\beta$-casein leads to differential digestion by gut mucosa. The digestion of $A 1$ $\beta$-casein in the gut by the action of digestive enzymes (pepsin, pancreatic elastase etc.) results in the cleavage between histidine and adjacent amino acid and a bioactive peptide called beta casomorphin-7 (BCM-7) is produced (Stewart et al., 1987; Lien et al., 1992). BCM-7 has opioid like activity and binds to opioid receptors and neural cells. It is thought that $\beta$-casein variant $A 1$ is to be considered as hazardous for human health. The hazardous health effects of A1 variant milk like arteriosclerosis, diabetes mellitus type-1 (Kaminski et al., 2007), autism, coronary heart disease (McLachlan, 2001; Laugesen and Elliott, 2003), atherosclerosis (Tailford et al., 2003) and sudden infant death syndrome (Sun et al., 2003). Besides, neurological disorders such as schizophrenia and autism (Woodford, 2006).
Department of Animal Genetics and Breeding, Mumbai Veterinary College, Mumbai-400 012, Maharashtra, India

Corresponding Author: Mahadeo P. Sawane, Department of Animal Genetics and Breeding, Mumbai Veterinary College, Mumbai-400 012, Maharashtra, India.

Email: drmahadeo.ms@gmail.com

How to cite this article: Kulkarni, T.V., Pawar, V.D., Deshmukh, R.S. and Sawane, M.P. (2022). Genotyping of HF Crossbred Breeding Bulls for A1/A2 Variant of $\beta$-Casein Gene. Indian Journal of Animal Research. DOI: 10.18805/IJAR.B-4726.

Submitted: 17-07-2021 Accepted: 02-11-2021 Online: 20-01-2022

A1 variant of $\beta$-casein gene is mostly found in the milk of European, USA, Australia and New Zealand cattle breeds. Holsteins and Ayrshires produces A1 milk as compared to other cattle breeds. In India, increased milk production has been targeted by crossing Indian cattle breeds with high milk yielding exotic cattle breeds. Therefore, there might be chances of introduction of A1 in Indian cattle population. There was remarkable increase in crossbred cattle population of India due to extensive use of cross breeding with HF and Jersey. Considering health hazards of $A 1$ variant of $\beta$-casein there is urgent need to find out the genotypes of breeding bulls for securing human health. It is also important to know whether there is a definite health benefit to milk containing the A2 genetic variant and requires further investigation unlike harmful effects of $A 1$ milk. The present study was aimed out to know the status of $A 1$ and A2 allele in HF crossbred breeding bull population of Maharashtra state used at Al station. 


\section{MATERIALS AND METHODS}

The present research was carried out at 'Genetic Investigation Laboratory', Department of Animal Genetics and Breeding, Mumbai Veterinary College, Mumbai during the year 2018-2019. A total of 47 blood samples of HF crossbred breeding bulls were collected from Frozen Semen Laboratory, Kharki, Pune and FSL, Harsool, Aurangabad. The Genomic DNA was isolated by using phenol-chloroform method (Sambrook and Russell, 2006). Two different sets of primer were used to amplify $121 \mathrm{bp}$ and $244 \mathrm{bp}$ fragment of $\beta$-casein gene. Primer set used to amplify $121 \mathrm{bp}$ fragment as: F- 5' CCT TCT TTC CAG GAT GAA CTC CAG G 3' and R- 5' GAG TAAGAG GAG GGA TGT TTT GTG GGA GGC TCT 3' (McLachlan, 2006). The 244bp fragments were amplified by using three primers set: F- (A) - 5' CTT CCC TGG GCC CAT CCA 3'; F(C)-5' CTT CCC TGG GCC CAT CCC 3' and R- 5' AGG GAA GGG CAT TTC TTT GT 3' (Ganguly et al, 2013a). Here, the combination of primer ' $A$ ' and common reverse primer ' $R$ ' resulted into $A 1$ allele amplification and combination of primer ' $C$ ' and common reverse primer ' $R$ ' resulted A2 allele amplification. This set of primer was used to validate the results obtained for 121 bp fragment. The amplification of $121 \mathrm{bp}$ was carried out at $58^{\circ} \mathrm{C}$ annealing temperature and the amplification parameters are shown in Table 1. Similarly, amplification parameters of 244 bp fragment are shown in Table 2.

The PCR products were visualized on 1.7 per cent agarose gel. Further, the PCR products of $121 \mathrm{bp}$ were subjected to RE digestion with Ddel, Digestion was carried out in water bath at $37^{\circ} \mathrm{C}$ for 5 hours in total $20.00 \mu$ reaction mixture comprising of RE Ddel :1.0 $\mu$ l, 10Xk-buffer: $2.0 \mu \mathrm{l}$, PCR-product: $12.00 \mu \mathrm{l}$ and nuclease free water: $5.00 \mu \mathrm{l}$. RE

Table 1: PCR thermal cycles for CNS 2 (121 bp) locus amplification.

\begin{tabular}{lcc}
\hline Steps & Temperature & Time \\
\hline Initial denaturation & $95^{\circ} \mathrm{C}$ & $5 \mathrm{~min}$ \\
Denaturation & $94^{\circ} \mathrm{C}$ & $40 \mathrm{seC}$ \\
Annealing & $58^{\circ} \mathrm{C}$ & $30 \mathrm{seC}$ \\
Extension & $72^{\circ} \mathrm{C}$ & $1.5 \mathrm{~min}$ \\
& $(\mathbf{s t e p ~ 2 - 4 ) ~} \mathbf{3 0}$ cycles & \\
Final extension & $72^{\circ} \mathrm{C}$ & $5 \mathrm{~min}$ \\
\hline
\end{tabular}

Table 2: PCR thermal cycles for CNS2 (244 bp) locus amplification.

\begin{tabular}{lcc}
\hline Steps & Temperature & Time \\
\hline Initial denaturation & $94^{\circ} \mathrm{C}$ & $5 \mathrm{~min}$ \\
Denaturation & $94^{\circ} \mathrm{C}$ & $30 \mathrm{seC}$ \\
Annealing & $66^{\circ} \mathrm{C}$ & $30 \mathrm{seC}$ \\
Extension & $72^{\circ} \mathrm{C}$ & $30 \mathrm{seC}$ \\
& $(\mathbf{s t e p ~} \mathbf{2 - 4 )} \mathbf{5}$ cycles & \\
Denaturation & $94^{\circ} \mathrm{C}$ & $30 \mathrm{seC}$ \\
Annealing & $64^{\circ} \mathrm{C}$ & $30 \mathrm{seC}$ \\
Extension & $72^{\circ} \mathrm{C}$ & $30 \mathrm{seC}$ \\
& $(\mathbf{s t e p ~} \mathbf{2 - 4 )} \mathbf{3 0}$ cycles & \\
Final extension & $72^{\circ} \mathrm{C}$ & $5 \mathrm{~min}$ \\
\hline
\end{tabular}

digested products were electrophoresed on 4 per cent agarose gel containing Ethidium bromide (@ $10 \mu \mathrm{l} / 100 \mathrm{ml}$ ) at constant voltage of $90 \mathrm{~V}$ for 60 minutes using $1 \mathrm{X}$ TAE buffer.

\section{RESULTS AND DISCUSSION}

Variants of $\beta$-casein gene has been studied by the various scientists. In the present investigation, 47 crossbred breeding bull from Frozen Semen laboratory, Pune and Aurangabad Maharashtra state were genotype for A1, A2 varients of $\beta$-casein. The findings of the present study have been presented and discussed as under. The good quality bands of DNA fragments $121 \mathrm{bp}$ and $244 \mathrm{bp}$ of $\beta$-casein gene were amplified successfully at annealing temperature 58,66 and $64^{\circ} \mathrm{C}$, respectively. The DNA fragment of $121 \mathrm{bp}$ (Fig 1) of $\beta$-casein gene (exon 7) was successfully amplified with the primers as described by McLachlan (2006) and 244 bp (Fig 2) fragment of $\beta$-casein gene were successfully amplified by Allele Specific primers (Ganguly et al., 2013a). Ddel/PCR-RFLP (Fig 4) revealed two restriction patterns

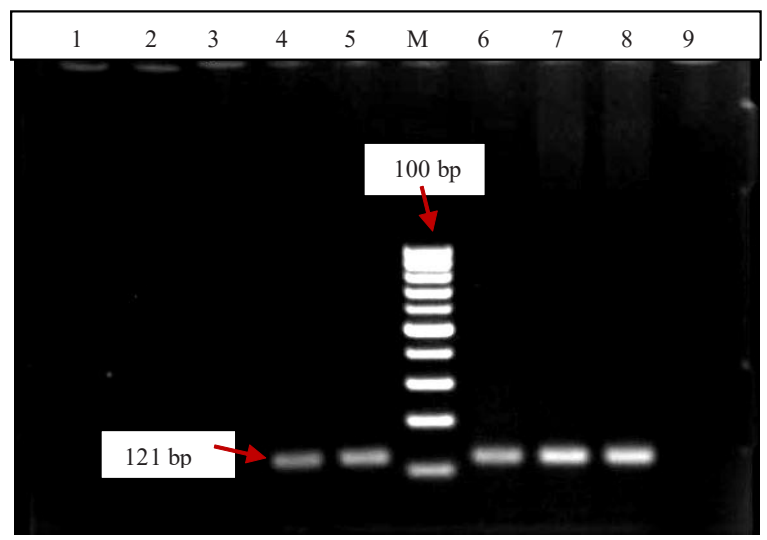

Fig 1: PCR amplicon of $121 \mathrm{bp}$ fragment of $\beta$ casein.

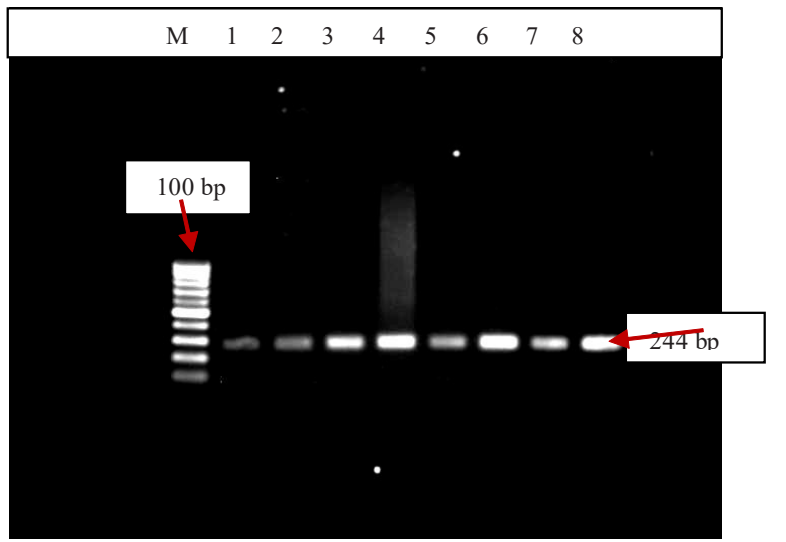

Fig 2: PCR amplicon of 244 bp fragment of $\beta$ casein gene.

Table 3: Gene and genotypic frequencies (121 bp and $244 \mathrm{bp}$ ).

\begin{tabular}{lccccc}
\hline \multirow{2}{*}{ Detail } & \multicolumn{3}{c}{ Genotypic frequency } & \multicolumn{2}{c}{ Allele frequency } \\
\cline { 2 - 6 } & A1A1 & A1A2 & A2A2 & A1 & A2 \\
\hline Exon-7 (121 bp) & 0.00 & 0.65 & 0.35 & 0.335 & 0.665 \\
Exon-7 (244 bp) & 0.00 & 0.73 & 0.27 & 0.36 & 0.64 \\
\hline
\end{tabular}


and were designated as $\mathrm{A} 1 \mathrm{~A} 2$ and $\mathrm{A} 2 \mathrm{~A} 2$ genotypes. The heterozygote $A 1 A 2$ pattern had three bands of size $121 \mathrm{bp}$, $86 \mathrm{bp}$ and $35 \mathrm{bp}$ and A2A2 pattern had two bands of size 86 $\mathrm{bp}$ and $35 \mathrm{bp}$. The band of $35 \mathrm{bp}$ was not visible in agarose gel. The estimated allelic frequency was found to be 0.335 and 0.665 for A1 and A2 allele (Table 3), respectively. The observed genotypic frequency for the genotypes A1A2 and A2A2 was, 0.65 and 0.35 (Table 3 ), respectively.

Present findings are partially in agreement with Shende et al. (2017) who reported only two genotypes A1A1 and A1A2 with frequencies of 0.28 and 0.72 in HF crossbred cows by PCR-RFLP analysis of $121 \mathrm{bp}$ fragment. Kumar et al. (2019a) observed all three genotypes in Vrindavani crossbred cattle with genotypic frequencies of 0.11 (A1A1), 0.47 (A1A2) and 0.42 (A2A2) and allelic frequencies of A1 and $A 2$ were 0.35 and 0.65 , respectively in Vrindavani cows. Many researchers reported that all indigenous cattle breeds and buffaloes are of A2 type. Whereas, the presence of A1A1 genotype in Vrindavani population indicates that these animals may belong to $F_{2}$ generation and backcrossed with exotic bulls resulting in A1A1 genotype. However, in Sahiwal cows, only two types of genotypes were observed with frequency of $0.13(\mathrm{~A} 1 \mathrm{~A} 2)$ and 0.87 (A2A2). The allelic frequencies for $A 1$ and $A 2$ were 0.06 and 0.94 , respectively in Sahiwal cows. Predominance of A2 allele was confirmed in indigenous and crossbred cattle, supporting the present findings. Further, Kumar et al. (2020) reported two genotypes in Tharparkar cattle i.e. A2A2 and A1A2, with A1 allele frequency as 0.04 , indicating very high frequency of $A 2$ variants. They found all three genotypes in Frieswal cattle, the genotype frequencies of $\mathrm{A} 1 \mathrm{~A} 1, \mathrm{~A} 1 \mathrm{~A} 2$ and $\mathrm{A} 2 \mathrm{~A} 2$ were found to be $0.17,0.39$ and 0.44 , respectively. The Frieswal cattle showed 0.37 for $A 1$ and 0.63 for $A 2$ allele frequencies which was in accordance with present findings indicating predominance of A2 allele in crossbred cattle.

Kumar et al. (2019b) analyzed association between $\beta$-Casein genotypes and different production and reproduction traits in Frieswal cattle. They found that A1A1 genotype cows had significantly lower TMY, MY300, PY and $\mathrm{DP}$ as compared to $\mathrm{A} 1 \mathrm{~A} 2$ and $\mathrm{A} 2 \mathrm{~A} 2$ genotypes. A1A2 genotype had highest TMY, MY300, PY and DP; however, A2A2 and A1A2 genotypes were not significantly different from each other. The results pointed towards the superiority of A2 $\beta$-casein variant for several production traits in crossbreds.

Whereas, Miluchová et al. (2013) studied same fragment of beta casein gene and reported three genotypes in HF crossbred cattle as A1A1, A1A2 and A2A2 with genotypic frequencies of $0.14,0.46$ and 0.40 , respectively and allelic frequency for $\mathrm{A} 1$ and $\mathrm{A} 2$ to be 0.30 and 0.70 , respectively. Mishra et al. (2009) genotyped 618 cattle (15 zebu cattle breeds), 231 buffaloes ( 8 river buffalo breeds) for $\beta$-casein gene polymorphism and reported the predominance of $\mathrm{A} 1$ in Bos taurus and $\mathrm{A} 2$ in zebu cattle breeds, while river buffaloes having only $A 2$ variant. Hanusova et al. (2010) amplified 121 bp of $\beta$-casein gene in 92 cows and 5 bulls and reported frequencies of $A 1$ and
A2 allele of CSN2 in cows to be 0.54 and 0.46 , respectively. CSN2 genotypic frequencies in cows were A1A1 (0.13), A1A2 (0.83) and A2A2 (0.04). Only A1A1 and A1A2 genotypes with frequencies 0.20 and 0.80 were found in bulls. High proportion of heterozygote individuals and genetic disequilibrium were recorded. Sodhi et al. (2012) reported predominance of the desirable A2 allele across all cattle types studied with a mean frequency of 0.645 .

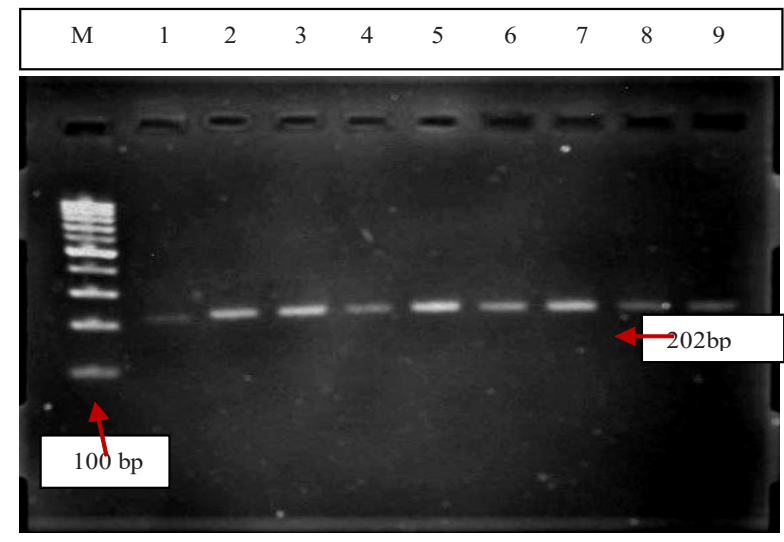

Fig 3: PCR amplicon of $202 \mathrm{bp}$ fragment of $\beta$-casein gene.

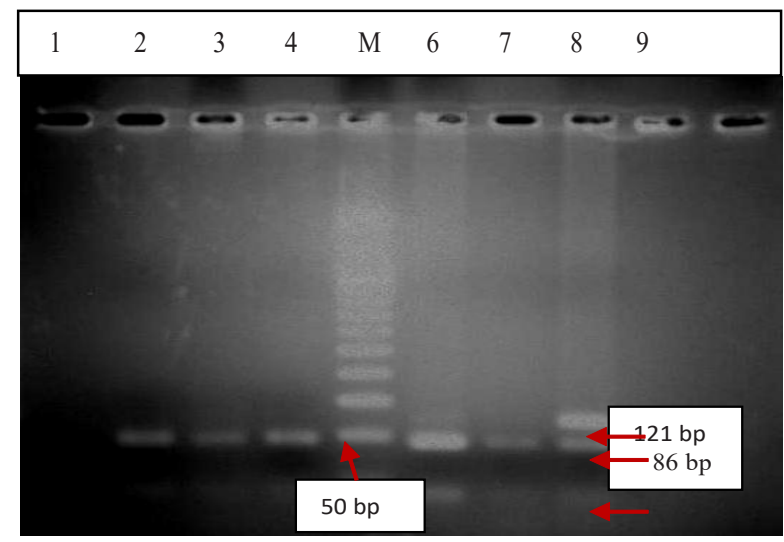

Fig 4: PCR-RFLP of $121 \mathrm{bp}$ fragment of $\beta$-casein gene. Lane: $6^{\text {th }}$ and $8^{\text {th }}$ - genotype A1A2 (121bp, $86 \mathrm{bp}$ and $\left.35 \mathrm{bp}\right)$; Lane: $2^{\text {nd }}, 3^{\text {rd }}, 4^{\text {th }}$ and $7^{\text {th }}$ - genotype A2A2 (86 bp and $35 \mathrm{bp}$ ).

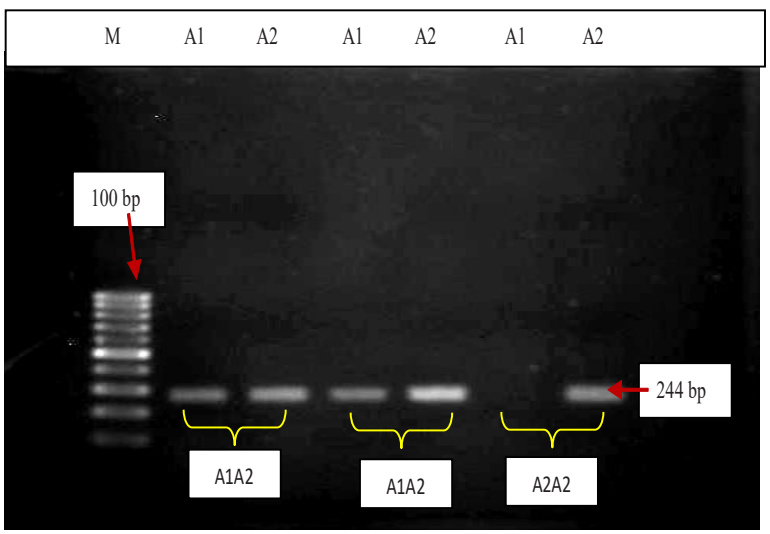

Fig 5: AS-PCR analysis of $\beta$-casein gene (244 bp). A1A2 (Lane $2^{\text {nd }}, 3^{\text {rd }}, 4^{\text {th }}$ and $5^{\text {th }}$ ) and $A 2 A 2$ (Lane $8^{\text {th }}$ ). 
The allele specific primers for the fragment of $244 \mathrm{bp}$ was used to validate the genotypes produced through Ddel/ PCR-RFLP of $121 \mathrm{bp}$. The AS-PCR amplification of $244 \mathrm{bp}$ (Fig 5) shown no amplification for $A 1$ allele by specific forward primer and common reverse primer. Whereas, amplification of 244 bp product with A2 allele specific forward primer with one common reverse primer revealed one band of $244 \mathrm{bp}$ in $13 \mathrm{HF}$ crossbred bulls. Amplification of $244 \mathrm{bp}$ fragment with both the allele specific (A1 and A2) forward primer and common reverse primer yielded two bands of $244 \mathrm{bp}$ representing $\mathrm{A} 1$ and A2 allele in 34 breeding bulls. Thus, the present study confirms that crossbred breeding bull population belongs to two genotypes viz. A1A2 and $A 2 A 2$ and A1A1 genotype was found to be absent in all breeding bulls under investigation. The frequencies of $A 1$ and $\mathrm{A} 2$ allele were found to be 0.36 and 0.64 respectively. The observed genotypic frequencies were as A1A1 (00), $A 1 A 2(0.73)$ and $A 2 A 2(0.27)$. The sequence analysis of 202 bp (Fig 3) fragment validated the genotypes by ASPCR of 244 bp fragment.

Five genotypes of $\beta$-casein gene i.e. A1, A2, A3, A5 and $B$ reported by using allele specific PCR (Lindersson et al., 1995). Similarly, differences in $\beta$-casein variant were evaluated in bovine breeds by using AS-PCR and relevance to BCM. Further, differentiation of $A 1$ and $A 2$ alleles was carried out by AS-PCR and observed genotypic frequencies of A1/A1 about 21.4 per cent, A2/A2 about 30.9 and A1/A2 about 47.6 (Keating et al., 2008). Slovak Pinzgau cattle population was studied for $\beta$-casein gene polymorphism and analyzed genotype structure. They reported heterozygous A1/A2 cattle with frequency of 0.52 while homozygous A2/ A2 cattle with frequency of 0.02 . This suggests a slight superiority of allele A1 (Miluchova et al., 2009).

The $321 \mathrm{bp}$ fragment of $\beta$ casein gene was amplified in 478 bulls to screen the A1/A2 allele status by using PCRACRS and then digested with the $M p h l$ enzyme resulted into 3 genotypes A1A1 (12.8\%), A1A2 (44.1\%) and A2A2 (43.1\%). The estimated allele frequency for $A 1$ and $A 2$ allele was 0.35 and 0.65 respectively (Olenski et al., 2010). The $362 \mathrm{bp}$ of exon 7 of beta casein gene was amplified and subjected for sequencing to study the A1/A2 polymorphism in Gir (68) and Guzerá. Allele frequencies were 98 and 97 per cent for the $\mathrm{A} 2$ allele and 0.96 and 0.93 per cent for the genotype A2A2 for Gir and Guzerá, respectively (Rangel et al., 2017). Ramesha et al. (2016) studied polymorphism of $\beta$ casein gene in breeding bulls of seven cattle breeds and two buffalo breeds by using PCR-ACRS amplification of $251 \mathrm{bp}$ fragment with Taql enzyme. They observed only A2 allele in Deoni and Khillar cattle and also in Murrah and Surti buffaloes. In the remaining cattle breeds they observed two genotypes $A 1 A 2$ and $A 2 A 2$. The frequency of $A 1$ allele was very low in MalnadGidda (0.014), Kasargod variety $(0.042)$ and Jersey (0.077), while the frequency of A1 allele in Holstein Friesian and Holstein Friesian crossbred males was 0.169 and 0.294 , respectively.
The present result for AS-PCR was similar with (Rahman et al., 2016); they observed two genotypes in the studied population of cattle. But the frequency of A1 allele in the studied population was less than the present findings, approximately 0.20 (local breed) and 0.10 (crossbred). The $244 \mathrm{bp}$ fragment of beta casein gene was amplified by using AS-PCR. A1 and A2 allele specific primers were designed to determine A1/A2 polymorphism in the Indian Zebu cattle breed Ongole and crossbred cattle Frieswal (HF x Sahiwal). They observed three (A1A1, A1A2 and A2A2) genotypes in the Frieswal and two $A 1 A 2$ and $A 2 A 2$ in Ongole (Ganguly et al., 2013b).

Similarly, 244 bp product was amplified by using AS$\mathrm{PCR}$ in Kangeyam and Holstein Frisian crossbred cattle to study polymorphism of A1/A2 variants of beat casein gene. HF cross cattle breed showed three genotypes (A1A1, A1A2 and $A 2 A 2$ ) and Kangeyam cattle showed only $A 2 A 2$ genotype. Frequency of A2 allele was found higher than A1 in HF crossbred animals as 0.595 (Malarmathi et al., 2014).

\section{CONCLUSION}

Considering the health hazards and importance of $\mathrm{A} 1$ variant of beta casein gene there is urgent need to screen the breeding population (breeding bulls and bull mothers) of cattle for A1A2 allele and the said data may be utilized in formulating suitable breeding plans in order to minimize undesired $\mathrm{A} 1$ allele in future generations.

\section{ACKNOWLEDGEMENT}

We duly acknowledge the Associate Dean, Mumbai Veterinary College, Mumbai for permitting to undertake the said research work at Department of Animal Genetics and Breeding. Also, to the authority from Animal Husbandry Department, Govt. of Maharashtra for providing the blood samples and relevant data in planning and executing the present work in successfully manner.

\section{REFERENCES}

Ganguly I., Kumar S., Gaur G.K., Singh U., Kumar A., Kumar S., Sharma, A. (2013a). Status of b casein (CSN2) polymorphism in Frieswal (HF X Sahiwal Crossbred) cattle. International Journal of Biotechnology and Bioengineering Research. 4(3): 249-256.

Ganguly I., Gaur G.K., Singh U., Kumar S., Kumar S., Mann, S. (2013b). Beta-casein (CSN2) polymorphism in Ongole (Indian zebu) and Frieswal (HF× Sahiwal crossbred) cattle. Indian Journal of Biotechnology. 12: 195-198.

Hanusova E., Huba J., Oravcova M., Polak P., Vrtkova, I. (2010). Genetic variants of beta-casein in Holstein dairy cattle in Slovakia. Slovakian Journal of Animal Science. 43(2): 63-66.

Kamiñski S., Cieœliñska, A., Kostyra, E. (2007). Polymorphism of bovine beta-casein and its potential effecton human health. Journal of Applied Genetics. 48(3): 189-198.

Keating A. F., Smith T. J., Ross R. P., Cairns, M.T. (2008). A note on the evaluation of a beta-casein variant inbovine breeds by allele-specific PCR and relevance to b-casomorphin. Irish Journal of Agricultural and Food Research. 47: 99-104. 
Kumar, S., Singh, R.V., Chauhan, A., Kumar, A., Yadav, J.S. (2020). Analysis of beta-casein gene (CSN2) polymorphism in Tharparkar and Frieswal cattle. Indian Journal of Animal Research. 54(1): 1-5.

Kumar, A., Singh, R.V., Chauhan, A., Ilayakumar. K., Kumar, S., Kumar, A., Sonwane, A.,Kumar, S., Panigrahi, M. and Bhushan, B. (2019b) Genetic association analysis reveals significant effect of b-casein A1/A2 loci on production and reproduction traits in Frieswal crossbred cows. Biological Rhythm Research. 51(8): 1259-1272.

Kumar, S., Singh, R.V., Chauhan, A. (2019a). Molecular characterization of $A 1 / A 2$ beta-casein alleles in Vrindavani crossbred and Sahiwal cattle. Indian Journal of Animal Research. 53(2): 151-155.

Lien, S., Alestrom, P., Hubgland, H., Rogne, S. (1992). Detection of multiple beta-casein (CASB) alleles by amplification created restriction sites (ACRS). Animal Genetics. 23: 333-38

Laugesen, M. and Elliott, R. (2003). Ischaemic heart disease, type-1 diabetes and cow milk A1 beta-casein. New Zealand Medical Journal. 116: 1-19.

Lindersson, M., Lunden, A., Andersson, L. (1995). Genotyping bovine milk proteins using allele discriminatio by primer length and automated DNA sizing technology. Animal Genetics. 26(2): 67-72.

Malarmathi M., Kumar S., Parthiban, M. (2014). Analysis of ß-casein gene for $A 1$ and $A 2$ genotype using allele specific PCR in Kangeyam and Holstein Frisian crossbred catttle in Tamilnadu. Indian Journal of Veterinary and Animal Science Research. 43(4): 310-315.

Mclachlan, C.N.S. (2001). Beta-casein ischemic heart diseases mortality and other illnesses. Medicine Hypotheses. 56: 262-272.

McLachlan, C.N.S. (2006). U.S. Patent No. 7,094,949. Washington, DC: U.S. Patent and Trademark Office.

Miluchova, M., Trakovicka, A., Gábor, M. (2009). Analysis of polymorphism of beta casein of Slovak Pinzgaucattle by PCR-RFLP for allels A1 and A2. Scientific Papers Animal Science and Biotechnologies. 42(2): 288-292.

Miluchová, M., Gábor, M., Trakovická, A. (2013). Analysis of Slovak Spotted breed for bovine beta casein A1 variant as risk factor for human health. Acta Biochimica Polonica. 60(4): 799-801.

Mishra, B.P., Mukesh, M., Prakash, B., Sodhi, M., Kapila, R., Kishor, A., Kataria, R.R., Joshi, B.K., Bhaisin, B., Rasool, T.J., Bhujarbaruah, K.M. (2009). Status of milk protein, $\beta$-casein variants among Indian milch animals. Indian Journal of Animal Science. 79(7): 722-72.

Olenski, K., Kaminski, S., Szyda, J., Cieslinska, A. (2010). Polymorphism of the $\beta$-casein gene and its associations with breeding value for production traits of HolsteinFriesian bulls. Livestcok Science. 131: 137-140.
Rahman, S.M., Islam, A., Alam, M.M., Hossain, M.M.K., Alim, M.A., Salimmullah, M., Alam, J. (2016). Analysis of $\beta$-casein gene variants of milk in cattle. Proceedings of the $3^{\text {rd }}$ International Exhibition on Dairy Aqua and Pet organized by AHCAB, Bangladesh, at Bangabandhu International Conference Center, Dhaka. pp 45-50.

Ramesha, K.P., Rao, A., Basavaraju, M., Alex, R., Kataktalware, M.A., Jeyakumar, S., Varalakshmi, S. (2016). Genetic variants of $\beta$-casein in cattle and buffalo breeding bulls in Karnataka state of India. Indian Journal of Biotechnology. 15: 178181.

Rangel, A.H.N., Zaros, L.G., Lima, T.C., Borba, L.H.F., Novaes, L.P., Mota, L.F.M., Silva, M.S. (2017). Polymorphism in the $\beta$ Casein gene and analysis of milk characteristics in Gir and Guzerá dairy cattle. Genetics and Molecular Research. 16(2): gmr16029592.

Roginsky, H. (2003). Encyclopedia of Dairy Sciences. Academic Press, London.

Sambrook, J. and Russell, D.W. (2006). Purification of nucleic acids by extraction with phenol: Chloroform. ColdSpring Harbor Protocols. (1): 4455.

Sharma, V., Sharma, N., Singh, P.R., Jawed, B., Chandra, S. (2013). Amplification of the Bovine Beta Casein Gene-Relevance to Modern Human Health. Animal Journal of Pharmacology and Technology Research 3(1): 439-444.

Shende, T.C., Kulkarni, P.S., Pawar, P.C. (2017). Genotyping of HF crossbred cattle for $\beta$-casein genes using PCR-RFLP. Indian Research Journal of Extension Education (Special issue on Veterinary Research and Extension): 105-107.

Sodhi, M., Mukesh, M., Mishra, B.P., Kishore, A., Prakash, B., Kapil, R., Khate, K., Kataria, S., Joshi, B. (2012) Screening of taurine and crossbred breeding bulls for $\mathrm{A} 1 / \mathrm{A} 2$ variants of $\beta$-casein gene. Indian Journal of Animal Science. 82(2): 183-186

Stewart, A.F., Bonsing, J., Beattie, C.W., Shah, F., Willis, I.M., MacKnley, A.G. (1987). Complete nucleotide sequences of bovine as 2 and $\beta$ - casein cDNAs: Comparison with related sequences in other species. Molecular Biology and Evolution. 4: 231-24.

Sun, Z., Zhang, Z., Wang, X., Cade, R., Elmir, Z., Fregly, M. (2003) Relation of b-casomorphin to apnea in sudden infant death syndrome. Peptides 24: 937-943.

Tailford, K.A., Berry, C.L., Thomas, A.C., Campbell, J.H. (2003). A casein variant in cow's milk is atherogenic. Therosclerosis 170: $13-19$

Woodford, K.B. (2006). A critique of Truswell's A2 milk review. European Journal of Clinical Nutrition. 60(3): 437-439. 